\section{ANTI-LEUCOCIDIN AND MASTITIS PUERPERALIS}

BY

\author{
J. R. J. BÄNFFER, M.D. \\ Laboratory for Microbiology, State University, Utrecht, \\ The Netherlands
}

The local and general lesions in staphylococcal disease are generally ascribed-at least partly-to toxic substances and other soluble products produced by the staphylococci (Houser and Berry, 1961). The important role of $\alpha$-toxin is generally recognized. The occurrence of staphylococcal lesions in people with a high level of anti- $\alpha$-toxin in their serum proves that immunity against staphylococcal infections is due to more factors. Apart from antibacterial immunity the antitoxic immunity with regard to other toxins has to be considered.

The Panton-Valentine leucocidin, which damages human leucocytes but is not haemolytic, could possibly contribute to the development of local lesions. Panton and Valentine (1932) and Proom (1937) reported that staphylococcal strains from serious infections produced more leucocidin. (Cf. also Valentine, 1936 ; Valentine and Butler, 1939; Butler and Valentine, 1943.) Johanovsky (1958) also found a higher leucocidin production with strains from lesions than with strains from healthy carriers.

The work of Gladstone and van Heyningen (1957) and of Woodin $(1959,1960,1961)$ on the production and purification of this toxin has opened the possibility of studying the contribution of leucocidin in staphylococcal infection and of anti-leucocidin in immunity against such infections (Schwabacher and Salsbury, 1958; Towers and Gladstone, 1958 ; Towers, 1961).

Following Johanovsky (1958) we studied the influence of anti-leucocidin in the serum of newborn infants and their mothers on the frequency of staphylococcal infections in the period after confinement.

\section{Material and Methods}

Leucocidin was produced according to Gladstone and van Heyningen (1957) with strain V8 and purified over cárboxymethylcellulose (Woodin, 1960). Anti-leucocidin was estimated with human leucocytes and antiserum CPP 76/73 (Burroughs Wellcome) as a standard. This serum contains 240 A.U. per ml. (Woodin, 1960). Antitoxic units (A.U.) of anti-leucocidin given here refer to this standard.

Anti- $\alpha$-toxin determinations were kindly carried out by the Dutch Central Public Health Laboratory according to Dolman and Kitching (1935) with rabbit cells and an international standard serum.

All confinements were normal cases, occurring in the maternity clinic of the University of Utrecht during two periods. During the first (March 19 to August 17, 1960) 202 cases were studied against 152 during the second (November 11, 1960, to February 22, 1961). These two series of cases are referred to as series $\mathbf{A}$ and $\mathbf{B}$. Maternal blood was obtained immediately after confinement from the vena cubiti $\left(M_{I}\right)$. Blood from the placental stump $\left(\mathrm{N}_{\mathrm{I}}\right)$ of the cord was considered to represent the blood of the child, though Barr et al. (1949) found a difference in the titres of diphtheria antitoxin between cord blood and peripheral blood. In many cases it was possible to sample peripheral blood from mother and child two months later $\left(M_{I I}, N_{n}\right)$.

In series $A$ (202 cases) anti-leucocidin and anti- $\alpha$-toxin were determined in all samples from mother and child taken at the date of confinement and in the samples which could be obtained two months later from 152 mothers. In the samples obtained from 147 infants two months after birth only anti-leucocidin could be determined.

In series B (152 cases) anti-leucocidin was determined in all samples from mother and child taken at the date of confinement and from the samples which could be obtained from 130 mothers two months later. The children were not sampled at that time and no anti- $\alpha$ toxin was determined in this series unless infections were observed.

Only definite cases of mastitis puerperalis with fever and local infiltration and requiring treatment (by the family physician) were taken into account.

\section{Results}

Initial Antitoxin Titres in Maternal Blood and Cord Blood.-Johanovsky accepted the anti-leucocidin titre in cord blood as representative for the titre in maternal blood. Several authors reported differences in titre between cord blood and maternal blood (Bryce and Burnet, 1932 ; Murray et al., 1950 ; Dobiaś and Balló, 1958 ; Kienitz and Kümmel, 1960, for anti- $\alpha$-toxin ; Barr et al., 1949, for diphtheria antitoxin). For our material the frequency distributions of the titres of antileucocidin and anti- $\alpha$-toxin in cord blood $\left(\mathrm{N}_{\mathrm{J}}\right)$ and maternal blood $\left(M_{I}\right)$ are given in Figs. 1 and 2. For both toxins the mean titre is slightly higher in cord blood than in maternal blood. On comparing individual serum pairs the anti-leucocidin titre is higher in cord blood than in maternal blood in $36 \%$, equal in $54 \%$, and lower in $9 \%$. For anti- $\alpha$-toxin these data are $48 \%, 40 \%$, and $12 \%$ respectively. Whether this difference could be due to a concentration in the placenta, as is suggested by some authors, is difficult to decide. For the antileucocidin the difference is probably not due to nonspecific inhibitors from Wharton's jelly, as the same difference was found (Bänffer, 1961) when the antileucocidin was determined by haemagglutination of leucocidin-coated red cells.

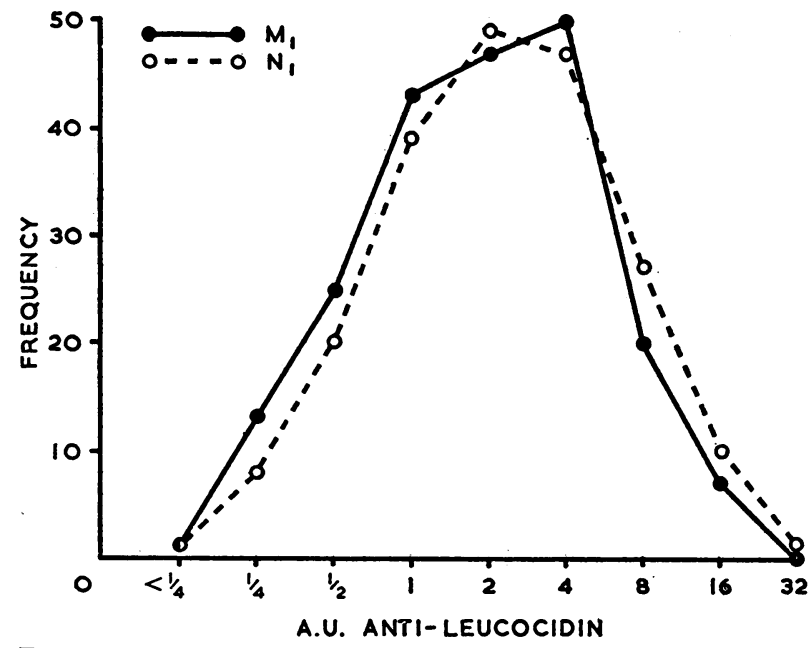

FIG. 1.-Frequency distribution of anti-leucocidin titres in maternal $\left(\mathrm{MI}_{\mathrm{I}}\right)$ and cord blood $\left(\mathrm{N}_{\mathrm{I}}\right)$ for 202 cases in series $\mathrm{A}$ Means: for $\mathrm{M}_{\mathrm{I}} 2.85$ A.U., for $\mathrm{N}_{\mathrm{I}} 3.69$ A.U. 
Decrease in Antitoxin Titres During the First Months of Life.-From 147 infants in series A serum samples at the time of birth $\left(\mathrm{N}_{\mathrm{I}}\right)$ and after two months $\left(\mathrm{N}_{\mathrm{II}}\right)$ were available. The frequency distribution of the antiP.V.-leucocidin in both sets of samples is given in Fig. 3. The titres in the second set $\left(\mathrm{N}_{\mathrm{UI}}\right)$ are much lower than in $\mathrm{N}_{\mathrm{I}}$. From the decrease of the means (3.68 to 1.03 A.U.) a mean half-life of about 30 days can be calculated. Titres decreased in 126 cases, were equal in 17 and increased in 4 . No manifest staphylococcal infections were observed in the latter. Seven staphylococcal infections were registered ( 2 mastitis, 3 furuncles, 1 panaritium, 1 nail infection). The inital titres in these

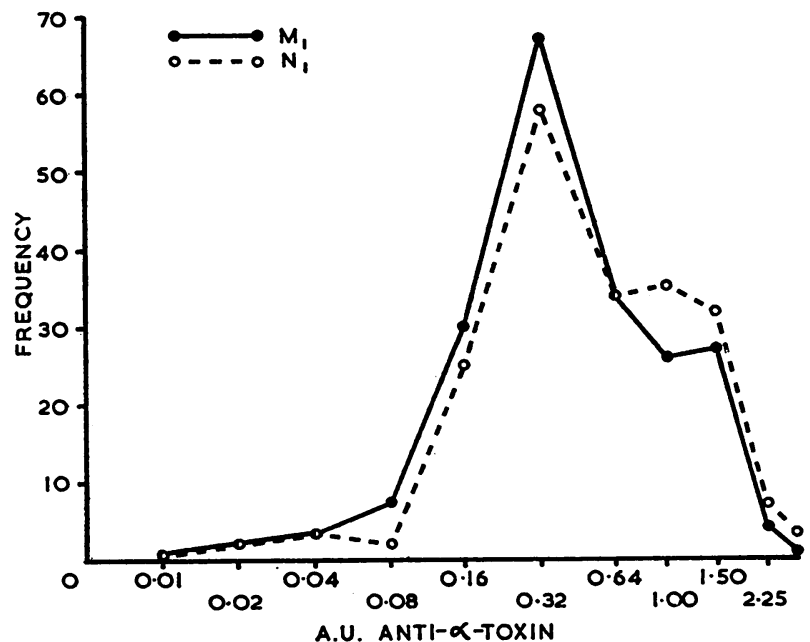

FIG. 2.-Frequency distribution of anti- $\alpha$-toxin titres in maternal (Mr.) and cord blood $\left(\mathrm{N}_{\mathrm{r}}\right)$ for 202 cases in series $\mathrm{A}$. Means: for $M_{I} 0.77$ A.U., for $N_{I} 0.92$ A.U.

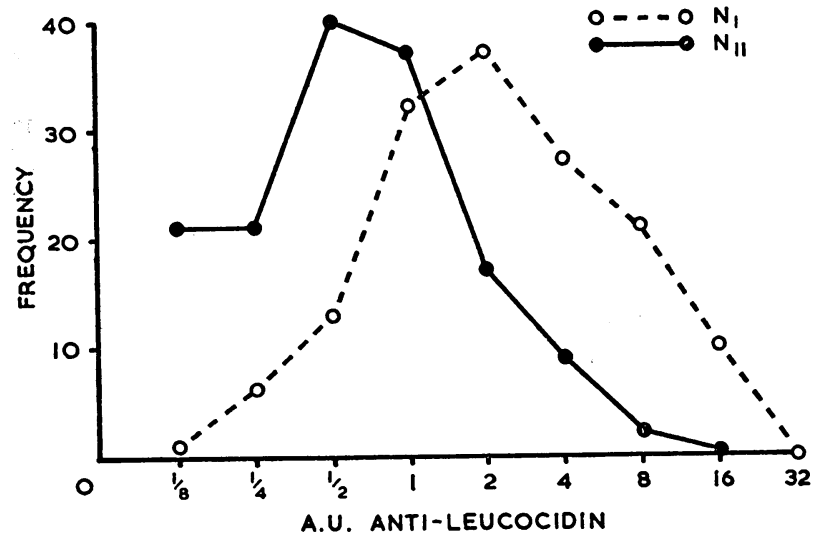

Fig. 3.-Frequency distribution of anti-leucocidin titres in cord blood $\left(\mathrm{N}_{\mathrm{I}}\right)$ and in the blood of the child two months after birth $\left(N_{\text {II }}\right)$ for 147 children in series A. Means: for $N_{1} 3.68$ A.U., for $\mathrm{N}_{\text {II }} 1.03$ A.U.

cases were not low $(4,4,4,4,2,16,2$ A.U. respectively) but all had decreased below 1 A.U. at two months. Considering the rapid decrease of anti-leucocidin titres nothing can be said about the titre at the onset of the infection $(1,2,5,5,3,7$, ? weeks after birth respectively). Anti-leucocidin titres in breast milk ( 23 cases) were low and could hardly have contributed to the titre of children.

Antitoxin Titres in Maternal Blood.-Complete data were available about 147 women from series $A$. The frequency distribution of the titres of both antitoxins in maternal sera is given in Figs. 4 and 5. The shift to the right of both curves indicates a general increase in titre in the period after birth. Analysis of data from individual pairs showed that it is mainly the group with low titres that increases. The correlation between the increase of anti- $\alpha$-toxin and anti-leucocidin for individual cases is shown in Table $\mathbf{I}$.

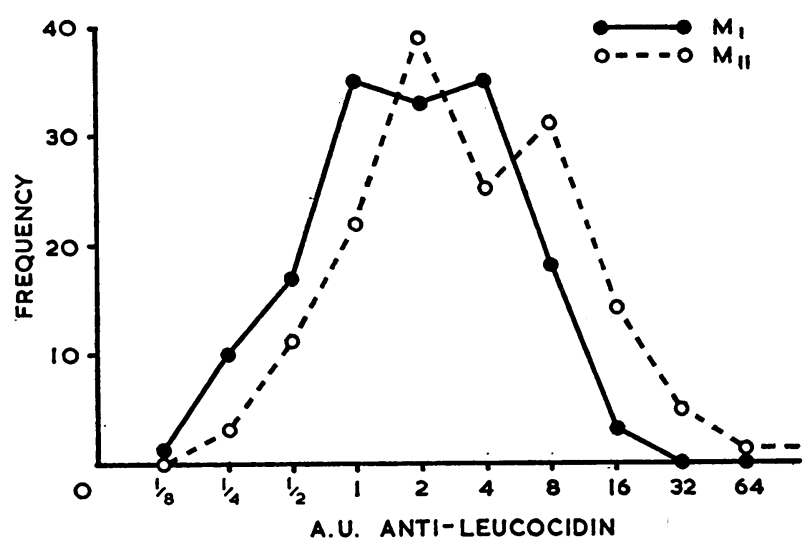

FIg. 4.-Frequency distribution of anti-leucocidin titres in maternal blood at confinement $\left(M_{1}\right)$ and two months later $\left(M_{11}\right)$ for 152 mothers in series A. Means: for $M_{1} 2.92$ A.U., for

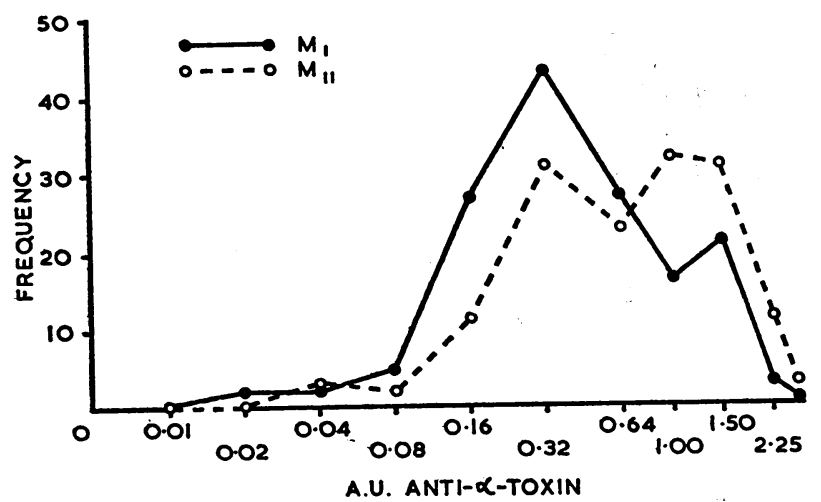

FIG. 5.-Frequency distribution of anti- $\alpha$-toxin titres in maternal blood at confinement $\left(\mathrm{M}_{\mathrm{I}}\right)$ and two months later $\left(\mathrm{M}_{\mathrm{II}}\right)$ for 152 mothers in series A. Means: for MI 0.72 A.U., for Mir 1.04 A.U.

TABLE I.-Correlation Between Increase and Decrease of Antileucocidin and Anti- $\alpha$-toxin Titre for Individual Cases in the Period After Confinement (Total: 147 Women)

\begin{tabular}{|c|c|c|c|c|}
\hline \multirow{2}{*}{ Anti-a-toxin } & \multicolumn{3}{|c|}{ Anti-P.V.-Leucocidin } & \multirow{2}{*}{ Tota } \\
\hline & Decrease & Equal & Increase & \\
\hline $\begin{array}{l}\text { Decrease } \\
\text { Equal } \\
\text { Increase }\end{array}$ & $\begin{array}{r}3 \\
3 \\
11\end{array}$ & $\begin{array}{r}8 \\
9 \\
37\end{array}$ & $\begin{array}{l}11 \\
14 \\
51\end{array}$ & $\begin{array}{l}22 \\
26 \\
99\end{array}$ \\
\hline Total . & 17 & 54 & 76 & 147 \\
\hline
\end{tabular}

Antitoxin Titres in Cases with Staphylococcal Infections.-The cases with infections occurring in both series are listed in Table II. During the infection the anti- $\alpha$ toxin titre had increased in 11 out of 18 cases; the antiP.V.-leucocidin titre had increased in all cases. Only the number of cases of mastitis puerperalis is large enough to permit further analysis.

Anti-leucocidin and Mastitis Puerperalis.-Complete data about the anti-P.V.-leucocidin in $M_{I}$ and $M_{I I}$ paired serum samples were available for both series. The distribution of cases of mastitis over the classes of women with various initial anti-leucocidin titres are given in Table III. There is a definite negative correlation between the initial titre and the occurrence of mastitis. By dividing the material in two 
groups with titres above and below 2 A.U. and testing the hypothesis that the occurrence of mastitis is random, a $P$ between 0.1 and 0.2 is obtained. The regularity of the decrease of the frequency of mastitis with increasing titre adds another factor. By combining the classes with titres $\frac{1}{4}$ and $\frac{1}{2}$ A.U. and those with 8 and 16 A.U. and applying Spearman's test a coefficient of correlation of -1 with a $\mathbf{P}$ of 0.008 is obtained.

Anti- $\alpha$-toxin and Mastitis Puerperalis.-Our data are much less complete here, as anti- $\alpha$-toxin was only determined routinely in series $A$. The distributon of mastitis over the classes with various titres in series $A$ (147 cases) is given in Table IV (third line). No obvious

TABLE II.-Staphylococcal Infections in Mothers of Series A

\begin{tabular}{|c|c|c|c|c|c|c|c|}
\hline & \multirow{2}{*}{ Age } & \multirow{2}{*}{ Parity } & \multirow{2}{*}{ Lesion } & \multicolumn{2}{|c|}{$\begin{array}{c}\text { Anti-leuc. } \\
\text { Titres }\end{array}$} & \multicolumn{2}{|c|}{$\begin{array}{c}\text { Anti-a-toxin } \\
\text { Titres }\end{array}$} \\
\hline & & & & $\mathbf{M}_{1}$ & $\mathbf{M}_{11}$ & $\mathbf{M}_{1}$ & $\mathbf{M}_{11}$ \\
\hline $\begin{array}{l}1 \\
2 \\
3 \\
4\end{array}$ & $\begin{array}{l}37 \\
31 \\
33 \\
33\end{array}$ & $\begin{array}{l}\text { II-para } \\
\text { V-,", } \\
\text { IV-", } \\
\text { II- ," }\end{array}$ & $\begin{array}{l}\text { Panaritium left thumb } \\
\text { Recurrent furuncles } \\
\text { Recurrent hordeola } \\
\text { Furuncles on left }\end{array}$ & $\begin{array}{l}2 \\
4 \\
2\end{array}$ & $\begin{array}{r}32 \\
8 \\
4 \\
\end{array}$ & $\begin{array}{l}0.24 \\
0.64 \\
0.32\end{array}$ & $\begin{array}{l}0.48 \\
1.00 \\
0.32\end{array}$ \\
\hline $\begin{array}{r}5 \\
6 \\
7 \\
7 \\
8 \\
9 \\
10 \\
11 \\
12 \\
13 \\
14 \\
15 \\
16 \\
17 \\
18\end{array}$ & $\begin{array}{l}21 \\
28 \\
27 \\
23 \\
24 \\
33 \\
36 \\
19 \\
21 \\
28 \\
23 \\
33 \\
19 \\
18\end{array}$ & 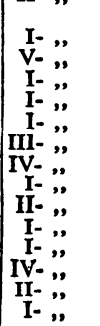 & $\begin{array}{c}\text { mamma } \\
\text { Mastitis } \\
\text { ", } \\
\text { ", } \\
\text { ", } \\
\text { ", } \\
\text { ", } \\
\text { ", } \\
\text { ", }\end{array}$ & $\begin{array}{l}2 \\
1 \\
0 \cdot 25 \\
0 \cdot 5 \\
0 \cdot 5 \\
2 \\
2 \\
2 \\
0 \cdot 5 \\
1 \\
0 \cdot 25 \\
0 \cdot 5 \\
1 \\
4 \\
1\end{array}$ & $\begin{array}{r}16 \\
16 \\
2 \\
1 \\
1 \\
2 \\
8 \\
64 \\
64 \\
128 \\
1 \\
2 \\
1 \\
1 \\
64 \\
2 \\
16 \\
2\end{array}$ & $\begin{array}{l}1 \cdot 50 \\
2 \cdot 25 \\
1 \cdot 00 \\
0.48 \\
0.24 \\
1 \cdot 25 \\
0 \cdot 24 \\
0.48 \\
0.48 \\
0 \cdot 64 \\
0 \cdot 32 \\
0 \cdot 32 \\
1 \cdot 50 \\
2 \cdot 25 \\
0.32\end{array}$ & $\begin{array}{l}2 \cdot 25 \\
2 \cdot 25 \\
1.00 \\
0.90 \\
1.00 \\
0.80 \\
2 \cdot 25 \\
5 \cdot 10 \\
0.64 \\
1 \cdot 50 \\
0 \cdot 64 \\
5 \cdot 07 \\
1.50 \\
2 \cdot 25 \\
0.32\end{array}$ \\
\hline
\end{tabular}

TABLE III.-Distribution of Cases of Mastitis in Classes of Various Anti-leucocidin Titres $\left(M_{1}\right)$ in 282 Women of Series $A$ and $B$

\begin{tabular}{|c|c|c|c|c|c|c|c|c|}
\hline & \multicolumn{7}{|c|}{ Anti-leucocidin (A.U.) in Class } \\
\hline & & $1 / 4$ & $1 / 2$ & 1 & 2 & 4 & 8 & 16 \\
\hline $\begin{array}{l}\text { No. of women } \\
\text { No. with mastitis } \\
\% \text { of class } \quad .\end{array}$ & $\because$. & $\begin{array}{l}17 \\
2 \\
11.8\end{array}$ & $\begin{array}{l}35 \\
4 \\
11 \cdot 4\end{array}$ & $\begin{array}{c}63 \\
5 \\
7.9\end{array}$ & $\begin{array}{c}65 \\
2 \\
3 \cdot 1\end{array}$ & $\begin{array}{c}61 \\
1 \\
1.6\end{array}$ & $\begin{array}{r}36 \\
0\end{array}$ & $\begin{array}{l}5 \\
0\end{array}$ \\
\hline
\end{tabular}

TABLE IV.-Distribution of Mastitis in Classes with Various Anti- $\alpha$-toxin Titres in Serum at Date of Confinement $\left(M_{\mathrm{I}}\right)$

\begin{tabular}{|c|c|c|c|c|c|c|}
\hline & \multicolumn{6}{|c|}{ Anti-a-toxin (A.U.) in Class } \\
\hline & $0 \cdot 16$ & 0.32 & 0.64 & 1 & 1.5 & $2 \cdot 25$ \\
\hline No. of women (series A) observed & 36 & 43 & 27 & 16 & 21 & 4 \\
\hline $\begin{array}{c}\text { "lated" ". } \\
\text { No. with mastitis (series A) }\end{array}$ & $\begin{array}{r}32 \\
2\end{array}$ & $\begin{array}{r}38 \\
2 \\
4\end{array}$ & 24 & $\begin{array}{r}14 \\
2\end{array}$ & 19 & 4 \\
\hline 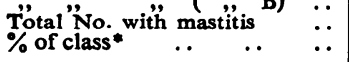 & $\begin{array}{l}\mathbf{2} \\
\mathbf{2} \cdot 9\end{array}$ & $\begin{array}{l}4 \\
6 \\
7 \cdot 4\end{array}$ & $\begin{array}{l}1 \\
1 \\
2 \cdot 0\end{array}$ & $\begin{array}{l}2 \\
6 \cdot 7\end{array}$ & $\begin{array}{l}1 \\
2 \cdot 5\end{array}$ & $\begin{array}{r}1 \\
25\end{array}$ \\
\hline
\end{tabular}

* Assuming an equal distribution of anti-a-toxin titres in the 130 women of series $B$ as in series A.

correlation between anti- $\alpha$-toxin and mastitis exists. The number of cases is too small to permit conclusions. Now in series B seven cases of mastitis occurred, and the initial titres of anti- $\alpha$-toxin were determined for these cases. As it is improbable that the frequency distribution of anti- $\alpha$-toxin in series B would materially differ from series $A$ the seven cases of mastitis are added in Table IV, fourth line. Obviously no correlation exists between anti- $\alpha$-toxin and mastitis. In fact, the frequency of mastitis in the class with highest titre is large.

\section{Discussion}

Our data establish a negative correlation between mastitis puerperalis and the anti-leucocidin titre in maternal blood at the time of confinement. No such correlation exists with the anti- $\alpha$-toxin titre.

Our material confirms the observations of Johanovsky so far as maternal infections are concerned. The possibility that a high anti-leucocidin titre might protect against mastitis has to be considered seriously.

Johanovsky also observed a negative correlation between initial anti-leucocidin titre and infections in the newborn. In our material the number of infections in children was too low to permit conclusions. Considering the rapid decrease of anti-leucocidin in the newborn one would expect theoretically that only early infections could be prevented.

NoTE.-Gladstone et al. (1962) and Markham (1962) have now published their results with separate determinations of antibodies against the two components of leucocidin. In most of their cases the titres of these two antibodies in one individual did not differ strongly. In our titrations the antibody with the highest titre (which obviously is the more important) would determine the result. Gladstone $e t$ al. found a mean titre of two antitoxin units in non-immunized individuals, whch compares well with our mean titre of 2.92 A.U. in women before confinement.

\section{Summary}

Anti-leucocidin and anti- $\alpha$-toxin was determined in the blood of the newborn and their mothers at the date of confinement and two months later.

The antitoxin titre in maternal blood often increased during the observation period (Figs. 4 and 5). The antitoxin titres of the infants decreased materially in the first eight weeks of life (Fig. 3), with a mean half-life of about 30 days.

Mastitis puerperalis occurred more often in mothers with low initial titres of anti-leucocidin (Table III). This negative correlation between anti-leucocidin and the frequency of mastitis has a coefficient of correlation of -1 with $P=0.008$. No correlation existed between mastitis and initial anti- $\alpha$-toxin titres.

I am indebted to Professor Dr. K. C. Winkler for his interest and advice and to Miss E. Winsemius for her technical assistance.

\section{REFERENCES}

Bänffer, J. R. J. (1961). Thesis, Utrecht

Barr, M., Glenny, A. T., and Randall, K. J. (1949). Lancet, 2,

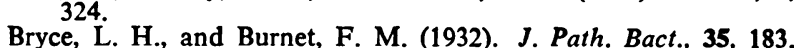

Butler, E. C. B., and Valentine, F. C. O. (1943). Lancet, 1, 194.

Dob́iaś, G., and Balló, T. (1958). Z. Immun.-Forsch., 116, 372.

Dolman, C. E., and Kitching, J. S. (1935). J. Path. Bact., 41, 137.

Gladstone, G. P., Mudd, S., Hochstein, H. D., and Lenhart, N. A. (1962), Brit. J. exp. Path., 43, 295 .

and van Heyningen, W. E. (1957). Ibid., 38, 123

Houser, E. D., and Berry, L. J. (1961). J. infect. Dis., 109, 24.

Johanovsky, J. (1958). Folia biol. (Praha), 4, 318. Kienitz, M., and Kümmel, J. (1960). Z. Immun.-Forsch., 120.

Markham, N. P. (1962). J. clin. Path., 15, 54.

Murray, J., Calman, R. M., and Lepine, A. (1950). Lancet, 2, 14

Panton, P. N.., and Valentine, F. C. O. (1932). Ibid., 1, 506

Proom, H. (1937). J. Path. Bact., 44, 425.

Schwabacher and Salsbury (1958).' J. clin. Path., 11, 417

- and Gladstone, G. P. (1958). Lancet, 2, 1192

Towers, A. G. (1961) ibid., 14, 161.

Valentine, F. C. O. (1936). Ibid., 1, 526.

- and Butler, E. C. (1939). Ibid., 1, 973.

Woodin, A. M. (1959). Biochem. J., 73, 225.

Woodin, A. M. (1959). Bioch (1961). J. Path. Bact., 81, 63. 